\title{
FRUCTOSE CONTENT OF MOUSE EJACULATES RECOVERED FROM THE UTERUS AFTER MATING
}

\author{
ANNA MARCHLEWSKA-KOJ \\ Department of Animal Genetics, Fagiellonian University, \\ Kraków, Poland
}

(Received 5th Fune 1970, revised 2nd October 1970)

\begin{abstract}
Summary. Fructose was determined in ejaculates of normal and vasectomized male mice, after recovery of the ejaculates from mated females. Approximately $70 \%$ of the total fructose remained in the copulatory plug and only $30 \%$ was present in the fluid portion of the seminal plasma. When the fluid portion of the ejaculate was left in the uterus for $2 \mathrm{hr}$ without contact with the plug (the uterine horn having been ligated), a statistically significant decrease of fructose occurred in relation to the initial value. When, however, such semen was left in the uterus in contact with the plug, this decrease was counterbalanced by an influx of fructose released from the plug.

No clear difference in the decrease of fructose content was found between the fluid portion of ejaculates from normal and vasectomized males after $2 \mathrm{hr}$ in the uterus.
\end{abstract}

\section{INTRODUCTION}

In some mammals, a portion of the seminal plasma forms a plug after copulation which closes the vagina. In mice, the formation of the vaginal plug results from an interaction of the secretions of the seminal vesicles and coagulating glands. The main energy source available to the spermatozoa in mammalian seminal plasma is fructose; the formation of fructose in mice as in other mammals is under the control of androgens (Thomas \& Strauss, 1965) and its content in the seminal plasma represents a sensitive androgen indicator test (Mann, 1964). The main difficulty in the use of the fructose test in mice arises from the fact that semen for analysis has to be recovered from the uterus after mating. Collection of semen by artificial vagina or electroejaculation has not proved to be practicable in mice.

The present study aimed at defining the fructose content of mouse semen, and determining the consumption of fructose by mouse spermatozoa.

\section{EXPERIMENTAL}

Crossbred $F_{1}$ males from KE females and KP males (Krzanowska, 1965), 2 to 3 months old and of tested fertility, were mated to oestrous outbred females. 
The mice were housed under mixed natural and artificial illumination with a constant light period ( 08.00 hours to 22.00 hours). They were fed freely, mainly on wheat and oats, and milk-soaked bread. The animals were mated at 08.00 hours and the females were subsequently checked every 10 min for the presence of the copulation plug. The males were not mated more frequently than every 7 days. Altogether, twenty-nine ejaculates from twelve normal and four vasectomized males were investigated.

Fructose was determined by the colorimetric method of Mann (1964).

\section{RESULTS}

\section{Experiment I}

Immediately after mating, the female was killed, the whole uterus excised and fructose determined in the contents of the uterus as well as in the vaginal plug. The male was also killed in order to determine the amount of fructose remaining in the accessory glands.

TABLE 1

FRUCTOSE CONTENT OF EJACULATES AND OF ACGESSORY GLANDS RECOVERED AFTER MATING FROM FEMALE AND MALE MIGE, RESPECTIVELY

\begin{tabular}{|c|c|c|c|c|c|}
\hline \multicolumn{3}{|c|}{$\begin{array}{l}\text { Fructose in ejaculates } \\
\text { recovered from females (mg) }\end{array}$} & \multicolumn{2}{|c|}{ Male accessory glands } & \multirow{2}{*}{$\begin{array}{l}\text { Body weight } \\
\text { of the } \\
\text { male } \\
(\mathrm{g})\end{array}$} \\
\hline $\begin{array}{l}\text { Uterine } \\
\text { contents }\end{array}$ & $\begin{array}{l}\text { Vaginal } \\
\text { plug }\end{array}$ & Total & $\begin{array}{l}\text { Fructose } \\
(m g)\end{array}$ & $\begin{array}{c}\text { Weight } \\
(m g)\end{array}$ & \\
\hline $\begin{array}{l}0.120 \\
0.220 \\
0.160 \\
0.210 \\
0.070 \\
0.130 \\
0.050 \\
0.030\end{array}$ & $\begin{array}{l}0.200 \\
0.500 \\
0.240 \\
0 \cdot 660 \\
0 \cdot 160 \\
0.240 \\
0.220 \\
0.440\end{array}$ & $\begin{array}{l}0.320 \\
0.720 \\
0.400 \\
0.870 \\
0.240 \\
0.370 \\
0.270 \\
0.470\end{array}$ & $\begin{array}{l}\text { N.D. } \\
3.300 \\
\text { N.D. } \\
\text { N.D. } \\
1.350 \\
0.730 \\
0.600 \\
0.850\end{array}$ & $\begin{array}{l}\text { N.D. } \\
430 \\
\text { N.D. } \\
\text { N.D. } \\
344 \\
213 \\
182 \\
220\end{array}$ & $\begin{array}{l}\text { N.D. } \\
32 \cdot 0 \\
\text { N.D. } \\
\text { N.D. } \\
24 \cdot 0 \\
23 \cdot 0 \\
23 \cdot 0 \\
26 \cdot 0\end{array}$ \\
\hline $\begin{array}{c}0.124 \\
\pm 0.071 * \\
27.4 \%\end{array}$ & $\begin{array}{r}0.332 \\
\pm 0.178 \\
72.6 \%\end{array}$ & $\begin{array}{r}0.457 \\
\pm 0.224 \\
100 \%\end{array}$ & $\begin{aligned} & 1 \cdot 366 \\
\pm & 1 \cdot 249 \dagger\end{aligned}$ & $\begin{array}{r}278 \\
\pm 105\end{array}$ & $\begin{array}{r}25 \cdot 6 \\
\pm 3 \cdot 8\end{array}$ \\
\hline
\end{tabular}

The fructose content in the uterus immediately after copulation varied greatly between ejaculates. In all instances, however, the uterine fructose constituted only part $(27.4 \%$ on average) of the total ejaculated fructose, while the remaining part ( $72.6 \%$ on average) was confined to the plug (Table 1$)$. Total ejaculated fructose constituted approximately one third of the amount that was still left in the accessory glands of the male. There were large differences between males in the amount of fructose in the accessory glands, due chiefly to the variable weight of these organs. In Table 1, the weight of these glands has been correlated with the body weight. 
Experiment 2

Immediately after mating, the female was anaesthetized with ether and the left horn of the uterus was removed in order to determine the fructose content. The right horn was left in contact with the vaginal plug for $2 \mathrm{hr}$. The female was

TABLE 2

FRUGTOSE CONTENT IN THE VAGINAL PLUGS AND IN THE FLUID PORTION OF EJACULATES RECOVERED FROM THE UTERINE HORN

\begin{tabular}{|c|c|c|c|}
\hline \multirow[b]{2}{*}{ Source } & \multirow{2}{*}{$\begin{array}{c}\text { Fructose content } \\
\text { (mg) } \\
\text { immediately } \\
\text { after mating } \\
\text { (Mean } \pm \text { S.D.) }\end{array}$} & \multicolumn{2}{|c|}{ Fructose content (mg) after $2 \mathrm{hr}$} \\
\hline & & $\begin{array}{l}\text { Uterine horn in contact } \\
\text { with the plug } \\
\text { (Mean } \pm \text { S.D.) }\end{array}$ & $\begin{array}{l}\text { Uterine hom separated } \\
\text { from the plug } \\
\text { (Mean } \pm \text { S.D.) }\end{array}$ \\
\hline $\begin{array}{l}\text { Uterus* } \\
\text { Plug }\end{array}$ & $0.036 \pm 0.030$ & $\begin{array}{l}0.043 \pm 0.040 \\
0.212 \pm 0.107\end{array}$ & $=$ \\
\hline $\begin{array}{l}\text { Uterusł } \\
\text { Plug }\end{array}$ & 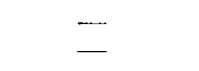 & $\begin{array}{l}0.050 \pm 0.026 \\
0.346 \pm 0.095\end{array}$ & $0.018 \pm 0.012$ \\
\hline $\begin{array}{l}\text { Uterus广̄ } \\
\text { Plug }\end{array}$ & $\begin{array}{l}0.050 \pm 0.014 \\
0.426 \pm 0.256\end{array}$ & - & $0.023 \pm 0.012$ \\
\hline $\begin{array}{l}\text { Uterus† } \\
\text { Plug }\end{array}$ & $\begin{array}{l}0.045 \pm 0.022 \\
0.256 \pm 0.068\end{array}$ & - & $0.021 \pm 0.010$ \\
\hline
\end{tabular}

* Six specimens.

$\dagger$ Five specimens.

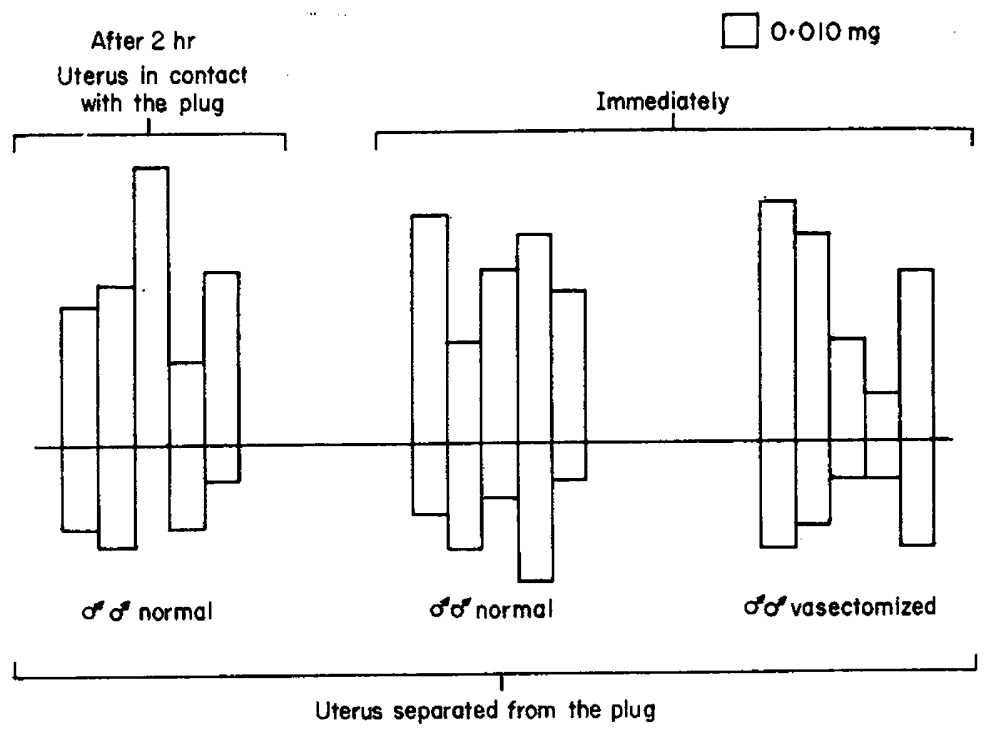

TEXT-FIG. 1. Fructose in the semen present in two horns of the uterus, immediately after copulation and $2 \mathrm{hr}$ later. Above the line-left horn; below the line-right horn (ligated).

then killed and the fructose content was estimated both in the horn and in the vaginal plug. No significant difference in the amount of fructose was observed between the two horns (Table 2). 


\section{Experiment 3}

Immediately after mating the left uterine horn was ligated and excised, and then returned into the peritoneal cavity, while the right horn was left intact, i.e. in contact with the vaginal plug. After $2 \mathrm{hr}$, the female was killed, the two horns and the plug were removed and the amounts of fructose compared.

It was found that the left horn of the uterus contained less fructose than the right one (Table 2). The differences, although statistically not significant, were observed in all cases (Text-fig. 1).

\section{Experiment 4}

The amounts of fructose in ejaculates derived from normal and vasectomized males were compared. Immediately after mating, the left uterine horn and the plug were removed in order to estimate the fructose content. The right horn was ligated and left in the peritoneal cavity for $2 \mathrm{hr}$.

In the seminal plasma left for $2 \mathrm{hr}$ in the uterus without contact with the plug, the fructose content markedly decreased in relation to the initial amount $(\mathrm{t}=2.95, P<0.02)$, both in normal and vasectomized males. On the other hand, no significant difference in the decrease of fructose content was observed between the ejaculates with or without the spermatozoa (Table 2).

\section{DISGUSSION}

An attempt was made to follow changes in the amount of fructose in ejaculates recovered from uteri of mice up to $2 \mathrm{hr}$ after mating, that is during the period when uterine spermatozoa show a high ability to fertilize ova (Krzanowska, 1966). Over $70 \%$ of fructose was found in the vaginal plug after copulation (Tables 1 and 2). As the plug gradually dissolved (Exp. 3, Table 2), fructose 'migrated' into the uterine fluid.

From the results of Exps 2, 3 and 4 (Table 2), it was concluded that during the period of $2 \mathrm{hr}$, the fructose content markedly decreased in the ejaculates recovered from uteri which had been disconnected from the plug. After $2 \mathrm{hr}$ in the uterine horns, there was no difference in the amounts of fructose remaining in ejaculates derived from normal and vasectomized males (Table 2, Text-fig. 1). Our results indicate that the utilization of fructose by mouse spermatozoa was relatively small despite the fact that the concentration of spermatozoa in these ejaculates is high, i.e. of the order of 11.6 million/ $\mu$ l (Krzanowska, 1962).

\section{REFERENCES}

Krzanowska, H. (1962) Sperm quantity and quality in inbred lines of mice and their crosses. Acta biol. cracov. 5, 279.

KrzanowsKa, H. (1965) New inbred strains of mice. Mouse News Lett. 32, 54.

KrzanOWSKa, H. (1966) Fertilization rate in mice after artificial insemination with epididymal or "capacitated" sperm from inbred and crossbred males. Folia biol., Krakbi, 14, 171.

MANN, T. (1964) The biochemistry of semen and of the male reproductive tract. Methuen, London.

Thomas, J. A. \& Strauss, A. J., JR (1965) The effect of steroids on mouse sex accessory fructose levels. Acta endocr., Copenh. 48, 619. 